\title{
Japanese Concept of Urban Promotion Control Area (UCA) to Save Agricultural Land in Bangladesh
}

\author{
Sharif Mohammad Tariquzzaman*
}

\begin{abstract}
Urban sprawling and unplanned infrastructure development are devouring productive land. Bangladesh is basically an agro based economy. In our country, about $1 \%$ of agricultural land in each year is transferred to another use. If this process continues all of our agricultural land would diminish within 100 years. This terrible situation is very crucial for an agro-based economy. In this paper, an attempt has been made to illustrate the necessity of introducing the Urban Promotion Control Area (UCA) in preparing physical development plan in Bangladesh to save agricultural land. This idea is well practiced in Japanese city planning. Unplanned development of physical infrastructure, especially development of unplanned road is the main cause of urban sprawling into the valuable agricultural land. The awful encroachment into the agricultural land also may cause haphazard urbanization. This type of land use regulation may protect the unpleasant encroachment into the UCA land. Public investment in UCA for urban infrastructure development could be strictly prohibited, so that unplanned development would be restricted.
\end{abstract}

\section{Introduction}

Bangladesh is predominantly an agricultural country, characterized by very low land man ratio. The rate of population growth is very high. At present national population growth rate of the country is about 1.48 percent and the rate of urbanization is nearly 7 percent per annum. The level of urbanization is 23.1 percent with more than 28 million people living in the urban area in 2001 (BBS 2001). The trend for the last few decades reveals that the growth of urban population has doubled in every 12 years. Although urbanization is a definite positive indicator of socioeconomic as well as physical development of the country, it also has some pessimistic impacts one of which is invasion of agricultural land. The high level of urbanization is mostly liable to diminish the agricultural land. In our country about $1 \%$ of agricultural land in each year is transferred to another use. Statistics show that the cultivable land in 1983-84 was 20-24 million acres and in 1997 it became 17.45 million acres (MOL, 2001). If such rate of uncontrolled urbanization continues, it would be very difficult to save the agricultural land of the country which may cause an alarming situation in near future. Recently, the utilization of agricultural land to the purpose of urbanization, is noticeably unplanned and unproductive and as such we are muddled with the complexities of unplanned growth. Thus a huge amount of agricultural land, being underutilized or utilized in non-productive ways, becomes wastage for the country like Bangladesh where land is the scarcest resource.

Now the question may arise, should we stop the urbanization process? The answer is 'no'. Actually urbanization does not mean the urbanized use of cultivable land. Urbanization is measured on the basis of the size of population enjoying urban facilities or living in urban areas. Thus urbanization must be continued with the process of densification in all urban areas of the country without unnecessary invasion of the cultivable land.

Japanese are practicing Urban Promotion Control Area system in their city planning exercise to protect urban sprawling. Area Division is determined in City Planning as a basic framework of the area to promote orderly urbanization and to control disorderly urbanization. Since City Planning Area is divided into Urbanization Promotion Area and Urbanization Control Area by a line, this

* Planner, Urban Development Directorate, Ministry of Housing and Public Works, Dhaka 
system is often called the "line-drawing system". This determines the size and shape of the future urban area. All types of urban promotion into this UCA are strictly prohibited. This type of area Division System was introduced in 1968 when Japan experienced drastic migration to the cities in the process of rapid industrialization and amazing economic growth. The present situation of Bangladesh is quite similar to the situation of Japan's 1968. Drastic migration to the cities is now taking place, rapid urbanization (2.7\%) is going on, urban sprawling is a vital factor to the country. Now we are observing a fast growing economy (GDP growth rate $7.0 \%$ ). So we can practice this type of landuse control regulation in our physical planning.

The objective of this study is to analyze Japanese Urban Promotion Control Area (UCA) technique in the context of their physical Planning System, to analyze agricultural land conversion situation in Bangladesh, to justify its adaptability in physical planning of Bangladesh and to formulate strategy and legal provisions to practice this type of system. This paper is prepared mainly on secondary materials. Field observation of Japanese cities that implemented the UCA technique in their physical planning was included.

\section{Scenario of Agricultural Land Conversion in Bangladesh}

Dhaka city has been growing at the expense of what were dense jackfruit and mango orchards in Savar, Gulshan, Banani and Uttara areas. The expansion of Khulna is reducing the coconut plantations of Phultala and Abhayanagar. These lands were not only good for horticulture, but also for Aus, Transplanted Aman, sugarcane and all kinds of dry land crops. Figure 1 shows the rapid urban growth in Savar area, an area just lying outside the Dhaka Metropolis.

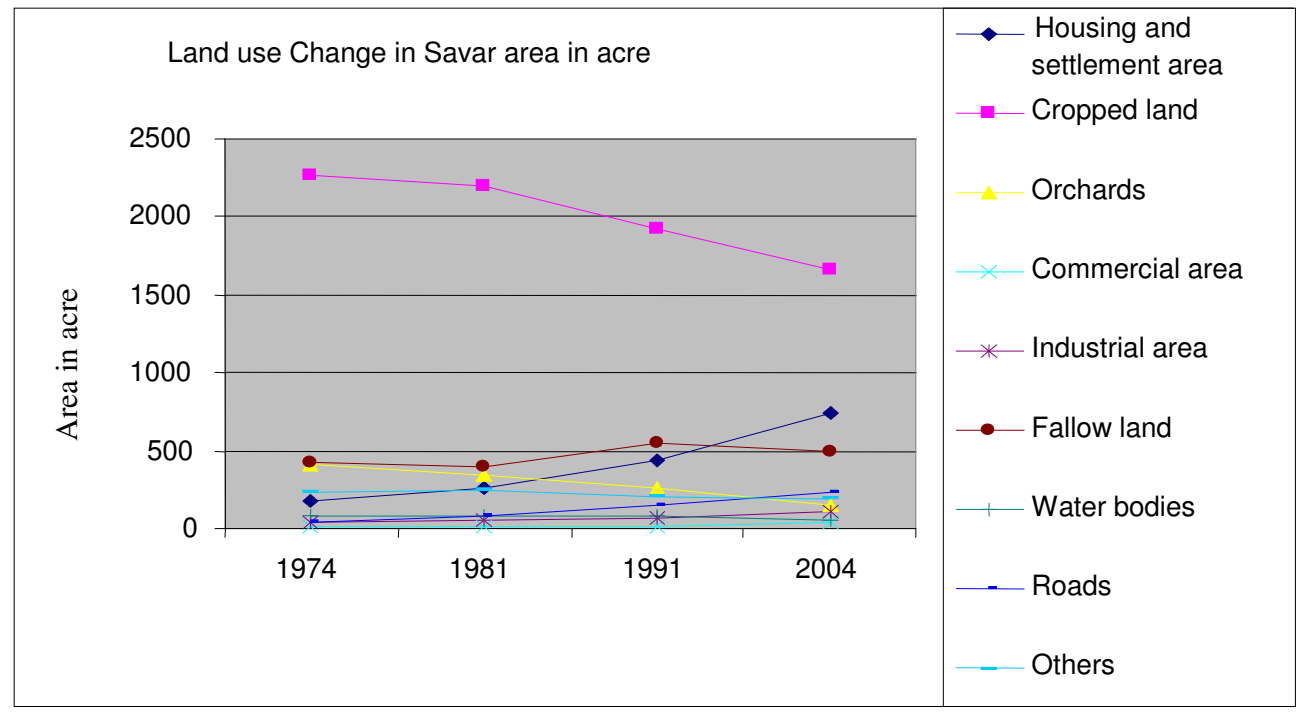

Source: Prepared from Fouzder, 2005

Fig. 1: Land use change in Savar area in acre

The rural roadways of the country have been constructed under Upazila or District programs through Upazila or Union Parishads (local level governments). Therefore, the road alignment was subject to the influence of local politicians and influential people. These unplanned infrastructure changes the landuse of the rural area, makes sprawling as well as ribbon development. A noteworthy feature of this alignment is that it follows the boundaries separating agricultural lands, rather than cutting through them. As a result, the actual length of the roads is often much longer than needed. A significant part of the roadways constructed under the rural road network program 
fall within the floodplain, with a view to easy road communication during the monsoon season between village to village, villages to markets and villages to some industrial units. Therefore, the road heights had to be kept above flood level, for which a significant portion of agricultural land was acquired for the roadway and the borrow pits along the sides of the roads.

\section{City Planning System in Japan}

Japanese planning system is a complex set of ingredients covering legal and legislative controls, plan-making, land use planning, zoning, control over population density etc. Planning in Japan is carried out at three levels - national, regional and local.

\section{National Comprehensive Development Plan}

National Comprehensive Development Plan is based on the Comprehensive National Land Development Act of 1950. After the enactment of this Act, Central Government has formulated four National Comprehensive Development Plans. These are: i) The First National Comprehensive Development Plan (1962- 1968) ii) The Second National Comprehensive Development Plan (1969-1976) iii) The third National Comprehensive Development Plan (1977-1988) and iv) The Fourth National Comprehensive Development Plan that started from 1989 (Srinivas, 2008).

In the First National Comprehensive Development Plan, 1962-1968, the Growth Pole development strategy was adopted to encourage the development of industrial cities away from the existing large metropolis. The Second National Comprehensive Development Plan, 1969-1976, attempted to construct a nationwide transportation network of motor ways and rapid national railways ('Shinkansen') system together with implementation of large-scale industrial development projects. The third National Comprehensive Development Plan, 1977-1988, set forth a settlement scheme which put emphasis on the creation of self-contained quality environments for human habitation. In the Fourth National Comprehensive Development Plan, 1989-to date, emphasis was given on the National Capital Region (NCR) and its positive role that it plays in the development of Japan as a whole (Srinivas, 2008).

\section{Regional Planning}

Japan is broadly divided into eight regions. There are the three largest metropolitan regions National Capital (Tokyo), Kinki (Osaka-Kobe-Kyoto), and Chubu (Nagoya) Regions. In addition to these, there are the Hokkaido, Shikoku, Kyushu, Tohoku and Chugoku Regions. The plans for NCR and the Kinki Region contain important strategic policies and projects, particularly industrial location control in central built-up areas, the development of industrial sites in suburban areas, large-scale new town plans, and the construction of metropolitan motor way networks. Green belts and other provisions in restricting physical urban expansion made under the First Plan (1958) could not be established - leading to planned urban development while preserving some of the green areas (Srinivas, 2008).

Most regional development acts were enacted in the 1960s with industrial and infrastructure provisions for special areas throughout the country. The Industrial Relocation Promotion Act of 1972, for example, specifies regions to which industry should be relocated and provides special financial assistance and tax incentives (Srinivas, 2008).

The Kinki Region Basic Plan (1965, 1971, 1978, and 1985) covers eight prefectures, including Osaka, Kyoto and Kobe metropolis. As with the NCR Basic Plans, the basic strategy is to encourage dispersal of population and industry from built-up areas to surrounding suburban and urban development areas. The Kinki Region, however, is rich in history and culture - and thus heritage conservation and preservation form important ingredients in the basic plans. This is complemented by further reinforcing the multi nuclei regional structure, and revitalization of regional economies with international linkages and information industries (Srinivas, 2008). 


\section{City Planning in Japan}

As cities in Japan grew in response to economic growth, the efficient construction and maintenance of urban infrastructure became an important issue in City Planning, covering allocation of spaces, and the safety and welfare of its residents. In Japan, urban and rural dichotomy is not clearly defined within the City Planning framework. Therefore 'City Planning' does not connote planning of 'cities', but more accurately implies 'physical planning in urbanizing or urbanized areas'.

\section{Area Division System in Japanese City Planning}

The City Planning Act of 1968 forms the basis for city planning in Japan. Area Division is determined in City Planning Area as a basic framework of the area to promote orderly urbanization and to control disorderly urbanization. Since City Planning Area is divided into Urbanization Promotion Area (UPA) and Urbanization Control Area (UCA) by a line, this system is often called the "line-drawing system". This determines the size and shape of the future urban area.

The division of the City Planning Area into two areas has two essential aims:

- Efficient development of urban facilities; and

- Prevention of uncontrolled development in forest and farmlands adjoining the existing built-up areas (JICA, 2007:11).

The Urbanization Promotion Area includes areas which already formed built-up area or areas which should be priority area for development in a planned manner within an approximate period of ten years. On the other hand, Urbanization Control Area is the area where urbanization should be restrained (JICA, 2007:11).

\section{Role Sharing of Related Agencies}

With these divisions as a base, the roles of city planning and agricultural administrations (Figure 2) are shared as follows:

- City planning administrations undertake the regulation of land use for urban purposes, the decision and development of public facilities, and implementation of Urban Development Projects in the Urbanization Promotion Area, and control land development activities in the Urbanization Promotion Control Area.

- Agricultural administrations control conversion of farmland for other purposes and investment for agricultural promotion in the Urbanization Control Area (JICA, 2007:11).

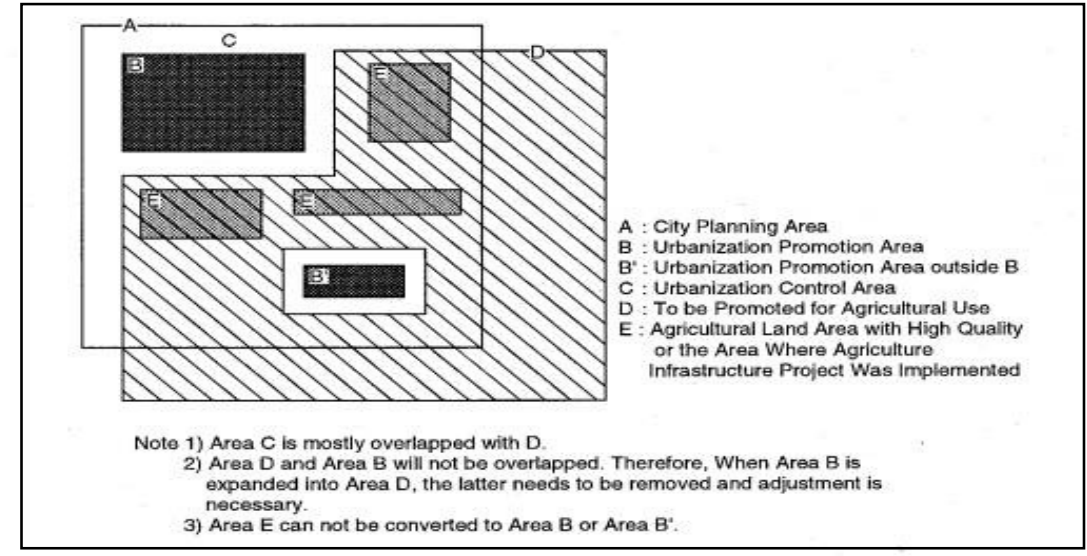

Source: JICA, 2007: 13

Fig. 2: Land use classification in city planning and agriculture 
Te legal effects of the Area Division are summarized in Table 1:

Table 1: The Legal Effects of Area Division

\begin{tabular}{|c|c|c|}
\hline Item & Urbanization Promotion Area & Urbanization Control Area \\
\hline Land Use Control & $\begin{array}{l}\text { Land use is controlled in accordance with } \\
\text { Land Use Zones, etc. for orderly use of } \\
\text { urban lands. }\end{array}$ & $\begin{array}{l}\text { Land use is regulated by plans from } \\
\text { the agricultural side. Land Use } \\
\text { Zones are not designated. }\end{array}$ \\
\hline Public Investment & $\begin{array}{l}\text { Public facilities, such as roads, parks, } \\
\text { sewerage, etc. are approved and public } \\
\text { investment will be actively carried out. }\end{array}$ & $\begin{array}{l}\text { Public investment for the promotion } \\
\text { of agriculture will be actively } \\
\text { carried out. }\end{array}$ \\
\hline $\begin{array}{l}\text { Urban Development } \\
\text { Project }\end{array}$ & Will be actively done & Will not be done. \\
\hline $\begin{array}{l}\text { Land Development } \\
\text { Permission }\end{array}$ & $\begin{array}{l}\text { For development of more than } 1000 \mathrm{~m}^{2} \text {, } \\
\text { approval by the prefectural governor is } \\
\text { necessary. Technical standards need to be } \\
\text { met. }\end{array}$ & $\begin{array}{l}\text { The urban development activities } \\
\text { are strictly controlled. }\end{array}$ \\
\hline $\begin{array}{l}\text { Conversion of } \\
\text { Farmland }\end{array}$ & $\begin{array}{l}\text { Mere report on the conversion is nec- } \\
\text { essary. }\end{array}$ & $\begin{array}{l}\text { Approval from the prefectural } \\
\text { governor is necessary. }\end{array}$ \\
\hline City Planning Tax & $\begin{array}{l}\text { City Planning Taxes may be collected to } \\
\text { generate revenue to fund City Planning } \\
\text { Projects. }\end{array}$ & Cannot be levied. \\
\hline
\end{tabular}

Source: JICA, 2007: 12

\section{Opportunity of UCA in Bangladesh}

With limited availability of agricultural land, further densification of population in urban land outside the core area of Dhaka as well as in urban areas of Bangladesh seems inevitable.

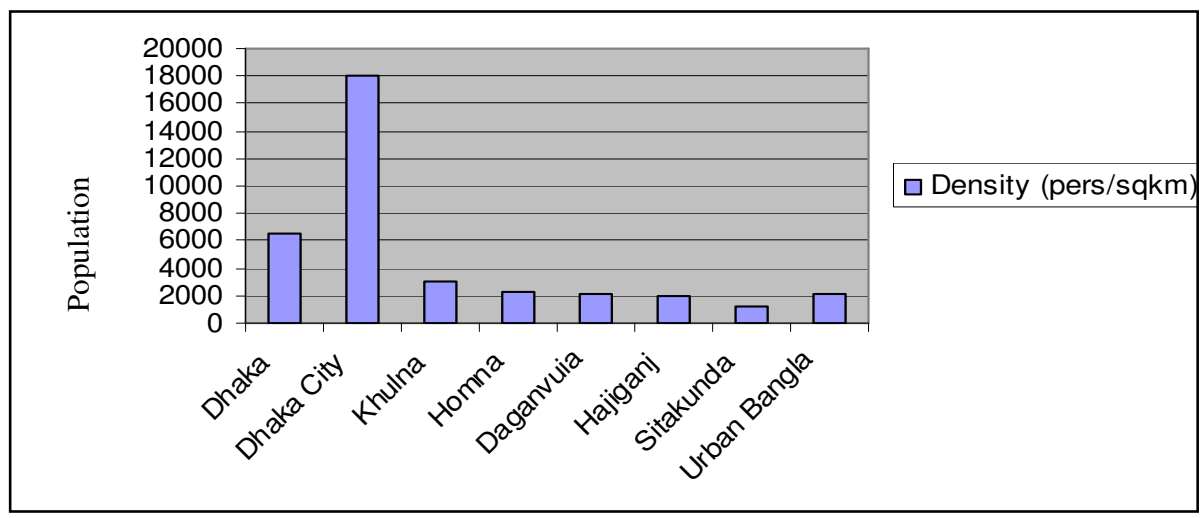

Source: BBS, 2005

Fig. 3: Urban population density

Figure 3 shows the density of some primary and secondary towns of Bangladesh. The density of population of Dhaka City Corporation is about 18000 persons per sq.km. and in the DMDP area 
about 6000 pers. Per sq.km. In the Khulna Development Authority area it is about 3000 persons per sq.km. The density of the secondary towns like Homna, Dagonvuia, Hajigonj is about 2000 pers. Per sq.km. More densification is possible in the secondary towns, categorized in three types of Paurashava towns - A, B and C, and also in the Metropolitan cities, like Khulna. In Figure 3, Homna, Daganvuia, Hajiganj and Sitakunda are Paurashava towns. Moreover, in the smaller towns, like union headquarters and growth centers, densification to a large extent is possible. So, we should decide to control the size of our towns to a limited extent. Japanese Urban Promotion Control Area (UCA) concept may be a good technique to deal with this situation.

\section{Concept of Urban Promotion Control Area in City Planning of Bangladesh}

In recent Planning practice, the concept of urban promotion control area is found in Bangladesh. This concept is used in four Metropolitan town Development plans. These plans were prepared within past fifteen years. The concept of Urban Promotion Control Area is used in these plans using a separate zone like agricultural zone, Flood Flow Zone etc. outside the Urban Area Plan zone (Urban Promotion Area). In the Structure Plan of Dhaka Metropolitan Development Plan (DMDP), Main Flood Flow zone, Sub Flood Flow Zone, Intensive Agricultural Zone are used. In Rajshahi Development Authority (RDA) area, Agricultural Conservation Area is used (Figure 4). In Khulna Development Authority (KDA) Structure Plan, a zone is used as unclassified zone. In all these Zones, development is restricted. But in practice the zone system is not working well. In the existing Urban Planning Laws of Bangladesh, there is no provision of urban promotion Control Area.

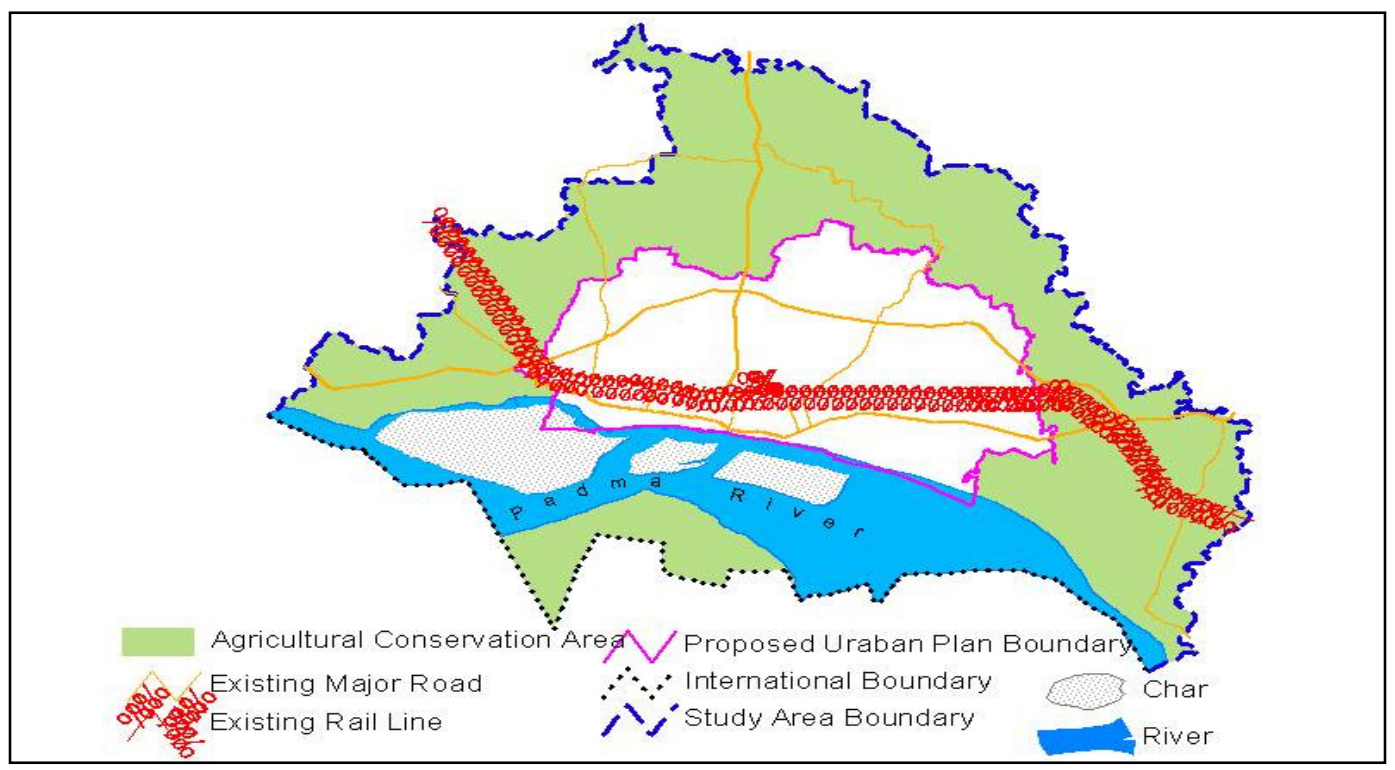

Source: RDA, 2004.

Fig 4: Agricultural Conservation Area outside the Urban Plan Boundary in Rajshahi Metropolitan Development Plan

\section{Strategy for Urban Promotion Control Area in Bangladesh}

\section{Preparing Development Plan}

For the balanced urbanization and coordinated physical development in all over the country, a countrywide National physical Plan is of utmost importance. This plan may have three phases, named National Comprehensive Development Plan, Regional Development Plan and Upazila 
Comprehensive Development Plan. In the National Comprehensive Development Plan sectoral physical strategy would be prepared. Definition of all types of urban centers, hierarchical order of the centers, ranking and the status of the centers, planning standards for the specific ranked centre, land use category for specific center, planning methodology for the specific center would be prepared in the National Comprehensive Development Plan. Action Area Plan for the special land uses, like Sundarbans, Hakaluki Haor etc. would be made. Nationally, strategic important infrastructures, like airport, national high way would be proposed in this plan. The Regional Development Plan for six regions (Division) would be prepared for narrowing the regional gaps and controlling the expansion of metropolitan regions. In these plans, the location of industrial zones and the universities would be defined. At the Upazila level, Upazila Comprehensive Development Plan would be prepared for whole Upazila. In this stage, Urban Promotion Area (UPA) and Urban Promotion Control Area (UCA) would be earmarked for all urban centers in the upazila.

\section{Legislative Measures}

It will also be necessary to make appropriate legislation for Urban Promotion and Urban Promotion Control. Some provisions should be introduced in this regard to the existing planning laws. For planned development and better management of urban areas, various Acts, Ordinances and Regulations were introduced in different periods. There is a number of planning related legislations in Bangladesh which help to regulate and control urban development activities. These are as follows:

- The Bengal Municipal Act, 1932 (Act XV of 1932)

- The East Bengal Building Construction Act, 1952

- The Town Improvement Act, 1953

- The Chittagong Development Authority Ordinance, 1959

- The Municipal Administration Ordinance, 1960

- The Khulna Development Authority Ordinance, 1961

- The Rajshahi Town Development Authority Ordinance, 1976

- The Dhaka City Corporation Ordinance, 1983 (XL of 1983)

- The Chittagong City Corporation Ordinance, 1982 (XXXV of 1982)

- The Khulna City Corporation Ordinance, 1984 (LXXII of 1984)

- The Rajshahi City Corporation Act, 1987 (Act 38 of 1987)

- The Sylhet City Corporation Act, 2001 (Act 10 of 2001)

- The Barisal City Corporation Act, 2001 (Act 11 of 2001)

- The Building Construction Regulation, 2006

The new law as well as the older laws should have some provisions for Urban Promotion and Urban Promotion Control area (Table 2). These are as follows:

The Urbanization Promotion Area includes areas which already formed built-up area or areas which should be priority area for development in a planned manner within an approximate period of ten years. On the other hand, Urbanization Control Area is the area where urbanization should be restrained.

- The Area Division is designated by following the ten-year objectives. The division is to be reviewed periodically in accordance with urbanization trends. The Urban Development Directorate is thus obliged to conduct Basic City Planning Surveys, basic surveys for each City Planning Area in approximately every 5 years. The survey covers the current situation and future prospects on population, industry, land use, transportation, etc. In addition to this, the results of person-trip surveys and commodity flow surveys, etc. are also used. 
Table 2: Proposed land use provision in the Urban Promotion Control Area (UCA)

\begin{tabular}{|c|c|c|c|}
\hline Land Uses & $\begin{array}{c}\text { Urban } \\
\text { Promotion } \\
\text { Control Area }\end{array}$ & Land Uses & $\begin{array}{c}\text { Urban } \\
\text { Promotion } \\
\text { Control } \\
\text { Area }\end{array}$ \\
\hline Agriculture. Forestry \& Grazing & $\mathrm{O}$ & Parking Facilities, Commercial & $\mathrm{N}$ \\
\hline Aquaculture \& Fisheries & $\mathrm{O}$ & Petrol Stations & $\mathrm{N}$ \\
\hline Brick Fields & $\mathrm{O}$ & Prisons & $\mathrm{N}$ \\
\hline $\begin{array}{l}\text { National, Regional Highway, } \\
\text { Railway }\end{array}$ & $\mathrm{O}$ & Public Uses \& Structures & $\mathrm{N}$ \\
\hline Other Types Of Road & $\mathrm{C}$ & Recreation Facilities, Outdoor & $\mathrm{O}$ \\
\hline Cemeteries / Graveyard & $\mathrm{O}$ & Religious Uses \& Structures & $\mathrm{N}$ \\
\hline Cinemas & $\mathrm{N}$ & Repair Shops, Major & $\mathrm{N}$ \\
\hline Clinics, Medical & $\mathrm{N}$ & Repair Shops. Minor & $\mathrm{N}$ \\
\hline Clubs & $\mathrm{N}$ & Retail Shops \& Restaurants & $\mathrm{N}$ \\
\hline Colleges \& Universities & $\mathrm{N}$ & Retention Ponds & $\mathrm{N}$ \\
\hline Docks \& Jetties & $\mathrm{O}$ & Salvage, Scrap Storage \& Processing & $\mathrm{N}$ \\
\hline Dwellings, Farm & $\mathrm{N}$ & Schools, Private & $\mathrm{N}$ \\
\hline Dwellings, Minimal Housing & $\mathrm{N}$ & Schools, Government, Religious & $\mathrm{N}$ \\
\hline Dwellings, Single/Multi Family & $\mathrm{N}$ & Ship \& Boat Servicing & $\mathrm{N}$ \\
\hline Embassies, High Commissions & $\mathrm{N}$ & Shopping Centres I Large Market & $\mathrm{N}$ \\
\hline $\begin{array}{l}\text { Explosives Manufacture \& } \\
\text { Storage }\end{array}$ & $\mathrm{N}$ & Stadium, Sports & $\mathrm{N}$ \\
\hline Flood Management Structures & $\mathrm{O}$ & Terminals, Train, Bus, Freight & $\mathrm{N}$ \\
\hline Golf Courses & $\mathrm{P}$ & Trade Centres & $\mathrm{N}$ \\
\hline Hospitals (With Morgue) & $\mathrm{N}$ & Utility Installations Type A & $\mathrm{O}$ \\
\hline Hotel Guest House & $\mathrm{N}$ & Utility Installations Type B & $\mathrm{O}$ \\
\hline Hotel International Class & $\mathrm{N}$ & Warehousing \& Distribution & $\mathrm{N}$ \\
\hline Industrial Class 2 & $\mathrm{~N}$ & Airport & $\mathrm{P}$ \\
\hline Industrial Class 3 & $\mathrm{~N}$ & Industrial And Commercial Structure & $\mathrm{N}$ \\
\hline Industrial Class 4 & $\mathrm{~N}$ & Open Space & $\mathrm{O}$ \\
\hline Institutions & $\mathrm{N}$ & Flood Flow & $\mathrm{O}$ \\
\hline Major Development & $\mathrm{N}$ & Waste Disposal \& Processing & $\mathrm{N}$ \\
\hline Offices / Services & $\mathrm{N}$ & & \\
\hline
\end{tabular}

Note: Permitted Use = O; Conditional Use $=\mathrm{C}$; Plan Review Required $=\mathrm{P}$ and Not Permitted $=\mathrm{N}$

- In Urbanization Promotion Area, land use is controlled in accordance with Land Use Zones, etc. for orderly use of urban lands. In Urbanization Control Area, land use is regulated by plans from the agricultural side. Land Use Zones are not designated.

- Public facilities such as roads, parks, sewerage, etc. are approved and public investment will be actively carried out in Urbanization Promotion Area. In Urbanization Control Area public investment for the promotion of agriculture will be actively carried out. 
- In Urbanization Promotion Area, urban development project will be actively done. In Urbanization Control Area, such development will not be done.

- For development of land in more than $1000 \mathrm{~m}^{2}$ in Urbanization Promotion Area, approval by the UDD/ Mayor of the City Corporation/ Paurashava is necessary. Technical standards need to be met. But in Urbanization Control Area, the urban development activities are strictly controlled.

- In Urbanization Promotion Area for the conversion of farm land mere report is necessary. But in Urbanization Control Area, approval from the Ministry of Housing and Public Works is necessary.

- In Urbanization Promotion Area, City Planning Taxes may be collected to generate revenue to fund City Planning Projects.

\section{Conclusion}

Japan introduced UCA type of land use regulation in 1968 while urban sprawling and migration occurred severely. They practiced this regulation firstly for their metropolitan cities and after successful implementation, they introduced it to their secondary towns. Now Japanese cities take regular shapes and they successfully extended the urban services to all settlement centers, whether urban and rural. Now migration and urban sprawling are not considered as problems in Japan. Successful implementation of Urban Promotion Control Area (UCA) and several other urban planning regulations lead to this balance city development. But in Bangladesh, migration and urban sprawling are considered as major problems that collapse our urban lives, especially in large cities. Urban sprawling reduces our valuable agricultural land. It should be stopped with proper physical planning. Urban Promotion Control Area (UCA) technique may be considered as a control measure in the physical planning of urban centers in Bangladesh. Japan introduced this technique by enacting City Planning Act of 1968. The Japanese are very obedient to their laws and regulations. So it was not difficult for them to implement this simple 'line drawing method' in physical planning in Japan. If we want to introduce this technique in our physical planning practices in the country, we should have strong legal support and political patronization. It should be ensured that no public and as well as private investment would be made contrasting to the provision of the Urban Promotion Control Area (UCA).

\section{References}

BBS 1997. Bangladesh Buroe of Statistics, Government of Bangladesh.

BBS, 2001. Bangladesh Buroe of Statistics, Government of Bangladesh.

Fouzder, 2005. Changing Pattern of Morphology and Land use in Savar Municipality of Dhaka, http:// (www.kfupm.edu.sa/crp/Kuwaitconference/Papers/577.pdf)

JICA, 2007. Urban Planning System in Japan, $2^{\text {nd }}$ Edition, Japan International Cooperation Agency in Cooperation with Ministry of Land, Infrastructure and Transport.

MOL, 1996. Lanuse Policy of Bangladesh, Ministry of Land, Government of Bangladesh.

RDA, 2004. Structure Plan Map (2004-2024), Structure Plan Master Plan and Detailed Area Plan of Rajshahi, Rajshahi Development Authority.

Srinivas, H. 2008. Japan Overview of Planning,

(http://www.gdrc.org/uem/observatory/jp-overview.html. ) 